\title{
7
}

\section{The Making of Our America: Hollywood in a Turkish Context}

Nezih Erdogan

This chapter examines the ways in which American cinema was represented in Turkey in the 1940s and the evidence for the existence of a growing connection between American cinema and the popular Turkish imagination during this period. It is based on an analysis of the popular film magazines of the time, as well as the memoirs and observations of writers interested in cinema. Issues of audience demand, of course, pose questions about the cultural identities involved in the experiences of identification and fantasy enjoyed by the film viewer. After describing the historical context in which American cinematic hegemony was established, the chapter will consider some of the ways in which Hollywood itself functioned as a kind of fantasy screen for the Turkish viewer. It will also touch upon European cinema since - as becomes particularly clear in the memoirs of film historian Giovanni Scognamillo - the tension between America and Europe, and thus between Hollywood and European cinema, is crucial to the mental machinery at work in the viewers' cinematic experience in its broadest sense.

These changes paralleled a number of political and sociocultural changes in Turkish society. In the two centuries leading up to World War II, the ongoing attempts at westernising Turkey were modelled on European patterns and precedents. By the mid1940s, however, Europe was in ruins. At least for the time being, it could not any longer act as the object of fascinated desire it had previously been. The United States inherited this mantle. Now, to the consternation of many pro-Europeans, Americanisation added its own cultural contradictions to such westernisation. ${ }^{1}$ As well as championing the values attached to freedom, it was more 'western' than any European country in terms of its wealth, technological prowess, and the scale of its cities (the year the war ended, a Chicago taxi driver proudly insisted on showing Falih Rifki, a Turkish journalist, the 'biggest' things in the world). ${ }^{2}$ In the post-1945 era, Turks found their thinking having to change to accommodate the rise of US power and influence. Their new perceptions revolved around a political axis that opposed America to the Soviet Union and a cultural axis that opposed America to Europe.

Although Turkey had not herself entered World War II, she still suffered from the pressures, restrictions, shortages and other damages it caused. This encouraged domestic social and political conflicts to rise to the surface. The western-oriented government found itself simultaneously under pressure from a nationalist movement with racist tendencies, an anti-western religious fundamentalist movement, and a left-wing movement based on an anti-imperialist discourse. These movements were treated by the 
Turkish government in a manner that was simultaneously very delicate, in order not to upset western allies, and very harsh. The leftist movement, in particular, was closely monitored and mercilessly repressed. Conservative Turkish governments were determined to ensure that Turkey herself opposed communism and remained part of the free world. Soviet agent Kim Philby recalls in his book, My Silent War, how in the mid-1940s Turkey was considered the first point of resistance against the Soviet Union in terms of a global war. ${ }^{3}$ The paranoia of the post-war years forced the West to try to defend Turkey against the threat from its old enemy, Russia, but during Philby's stay in Turkey (from 1946 to 1949), the United States took over this responsibility from the British. ${ }^{4}$ David J. Alvarez notes that Americans saw Turkey as an indispensable ally, because

policy-makers had decided that the independence of Turkey was vital to the security of the United States. They had concluded that the Soviet Union threatened that independence. Now they had committed America to assisting Turkey with arms and money, preferably through Great Britain but unilaterally if necessary. ${ }^{5}$

This beginning of a new alliance between two countries which did not really share any history together was symbolised by the visit of the American battleship Missouri in 1946, bringing home the body of the late Munir Ertegun, the Turkish Ambassador to the United States. ${ }^{6}$ The appearance of the Missouri might stand as a metaphor for the entrance of 'America' into Turkish life, and the most crucial steps in the development of Turkey's political and economic relations with the US were taken immediately after its arrival. ${ }^{7}$

\section{Early Patterns of Movie Distribution in Turkey}

The Turkish intelligentsia had sought to sponsor westernisation for many decades, encouraging in the process a eurocentric discourse. The introduction of cinema in Turkey immediately after the first screenings in Europe constituted a new space for this discourse. From the beginning, going to the movies was itself regarded as a western ritual. Sigmund Weinberg, a Polish Jew, arranged the first regular public screenings in Pera (now Beyoglu), a district of Istanbul where non-Muslim minorities had already adopted a much-envied western lifestyle. ${ }^{8}$ A great majority of early theatre managers belonged to minority groups, or to use the specific term, levantens. The European films they exhibited were intended to appeal to upper-class Turkish intellectuals as well as to the non-Muslim minorities of Pera, who spoke a variety of languages including Greek, Armenian, Hebrew, French, Italian and Spanish. Thanks to their special schooling, religious upbringing and their contacts in Europe, these managers had developed decidedly European tastes. The films they showed presented 'glamorous' scenes from various parts of Europe. One of the first screenings, for example, announced that it would make available 'For the first time in Istanbul (Constantinople), the magnificent and awesome show which brings in the whole of Paris. ${ }^{9}$ The audience was able to have access to these films almost immediately after they were produced. By offering virtual travel to Turkish audiences, early cinema represented a kind of visual colonialism. It implied a sort of double articulation: the Turkish audience could not only 'travel' around Europe while sitting in a movie-theatre, but could also travel around the movietheatres of the whole of Europe in a fantasy of westernisation. It was now possible to 
see the world from where the European viewer stood ('I am watching a film which the European viewer has also seen').

The first film companies to sell films in Istanbul were Lumière, Pathé, Gaumont and Ciné Theatrale d'Orient. After the pioneering activities of the Lumière brothers, Pathé authorised Sigmund Weinberg to distribute and exhibit their films in 1908, and the rest then followed. Consequently, early cinema in Turkey was predominantly French. Most of the first film magazines were bilingual - Opera-Ciné, Le Courrier du cinéma, ArtisticCiné, Ciné-Turc, Le Film and Ekran - and, next to Turkish or Ottoman, French was the necessary language of cinephilia. The movie-theatres, many of them part of a chain, followed the same pattern until the 1930s: Ciné-Palace, Orientaux, Central, Parlant, Gaumont, Artistic and Pathé. American films were also shown from a comparatively early stage. According to film historian Giovanni Scognamillo, the film magazine Musavver Türk Sinemasi made reference during the 1920s to companies such as Kemal Film, Opera Film and Fanamet Films Ltd, who were already importing films from Universal, United Artists, Paramount, First National and M-G-M. ${ }^{10}$ Theatre owners or managers had to provide a French title for American films, which were usually dubbed into French and subtitled in Turkish, or else subtitled in both French and Turkish. This continued until the 1950s, when Turkey began to enjoy closer cultural and economic/political relations with the US, including assistance from the Marshall Plan. ${ }^{11}$

The mid-1940s saw American cinema establishing its hegemony in Turkey. After war broke out in 1939, American films had gradually come to dominate the market, not only because of the crisis in the European film industries and difficulties in distribution, but also as a result of the rising popularity of the films themselves amongst Turkish audiences. Scognamillo comments that even though Turkish audiences were able to see some German UFA productions, French Vichy films, and also became acquainted with Hungarian cinema and liked it, Hollywood soon began to rule in the film market. The Turkish audience, he argues, wanted 'action, wealth, spectacularity and glamour ... excitement and emotion. They want dreams and they pay to have their dreams. ${ }^{12}$ Some theatre owners resisted this apparently growing American dominance by claiming that Italian movies (such as the melodramas of Amedeo Nazzari and Yvonne Sanson, together with the comedies of Toto), as well as British films (especially Arthur Rank productions) were also big box-office success. 'But it is American cinema after all', Scognamillo (himself a levanten) recalls:

[that] comes up with innovations - or they polish the old ones and present them as new - it dazzles, it fills the people with awe ... Marvellous are these American films, these Hollywood productions and they really add something to our view of the world, to our taste. ${ }^{13}$

By the 1940s the minority groups of Pera were no longer in a position to decide which films to import. Even with three expanding Turkish film companies, Ipek Film, Kemal Film and Lale Film, the increasing demand from Turkish audiences could only be met by American companies. ${ }^{14}$ Under the studio system, they were able to produce far more films than their European competitors and it was American-produced films that met the requirements of popular taste. A synchronicity now emerged between the domination of Hollywood and the domination of popular taste. As Andrew Higson observes, 
Hollywood is not only the most internationally powerful cinema - it has also, of course, for many years been an integral and naturalised part of the national culture, or the popular imagination, of most countries in which cinema is an established entertainment form. ${ }^{15}$

Hollywood itself presents a complicated Other to national cinemas - an Other that is both within and an alternative to national culture itself. Hollywood, of course, was not naturalised for European national cultures in the same way that it was naturalised for Turkish culture. Unlike European viewers of Hollywood, who were already westernised, Turkish viewers desired to achieve this condition. Hollywood's appeal to the Turkish viewer must in consequence be analysed in relation to specifically Turkish sociocultural and psychological dynamics, especially the roles played by identification and desire in forming Turkish identities.

\section{Identification and Desire in Turkish Popular Film Magazines}

Twenty film magazines were published between 1943 and 1947. Although many of them were short-lived, the figure indicates an increasing demand for information about Hollywood. Several of these magazines added the word 'Hollywood' to their titles. ${ }^{16}$ The editor of one new magazine, Sinema Alemi, explained its raison d'être:

Masses line up in front of the movie theatres just as they do in front of bakeries. Children play 'cowboys' in the streets. The best children games borrow their themes from the silver screen. Once, Paris was the pioneer of fashion. Now fashion is by and large influenced by the silver screen, particularly by Hollywood. Why all this? This is why we are publishing this magazine - to answer this question. ${ }^{17}$

Almost all the magazines devoted most of their pages to Hollywood. Through publicity materials, gossip columns, glamour photos, reviews, interviews and letters, they participated energetically in the construction of an image of 'Hollywood' and along with it an image of the 'American way of life'. Typical titles of articles included 'Hollywood creates vogue', 'Stars learning languages', 'Waists get thinner' and 'Tips from stars'. Writers focused their attention on love, sex, marriage, success and consumption, taking their material from Hollywood film companies' publicity departments, American film magazines and Turkish journalists who were then living in the United States. ${ }^{18}$ Such magazines gave little room to European cinemas. When a reader asked, for instance, for some information about what was going on in German cinema, the editor of Holivut Dunyasi (The World of Hollywood) answered that they were not able to receive any films even from Switzerland, which had not taken part in the war, let alone Germany. 'You would not want us to make up stories, would you?' he commented, perhaps facetiously. Obviously, European cinema was not able to exercise the same power of publicity as that generated by the efficient marketing machinery of Hollywood. ${ }^{19}$

Popular film magazines both encouraged and reflected a growing Turkish admiration for Hollywood stars. These magazines offered a reading of Hollywood that positioned the star at the centre and America (more properly, the 'American way of life') in the background. Richard Dyer sees stardom 'as a version of the American dream, organised around themes of consumption, success and ordinariness. Throughout, how- 
ever, there is an undertow that, as it were, "sours" the dream. In addition, love, marriage and sex are constants of the image. ${ }^{.20}$ Films themselves hold an off-centre position: references to films constitute a discourse that revolves around the star.

In February 1945, Holivut Dunyasi published a questionnaire, allegedly produced by an American studio, suggesting that 'if you can answer these questions, the doors of the studios can open for you'. It offers a fascinating and sometimes amusing view of how Turkish readers were invited to construct stardom. In reprinting (or, more probably, inventing) the questionnaire, the magazine's editors revealed a good deal about their own perceptions of stardom and personal beauty. The survey was split into three sections. The first, 'Beauty of Body', asked six questions:1. Do you have a beautiful face?; 2. Can you walk swiftly?; 3 . Does your hair cover your temples?; 4. (to women) Do you have beautiful hands?; 5. Do you have a nice profile?; and 6. Is there an elegance in the way you sit in an armchair? The second, 'Personality', wanted to know five things: 1. (to women) Do men like you?; 2. (to men) Do women like you?; 3. Are you well educated?; 4. Are you knowledgeable?; and 5. What makes you distinct when you are among other people? In the third and final section, on 'Artistry', respondents were asked seven questions: 1. Are you clever?; 2. Can you understand immediately what you are told?; 3 . Do you have a strong memory?; 4 . Do you have an accent?; 5. Can you express your feelings easily and communicate them to others?; 6. Have you ever experienced a disastrous event?; and 7. Do you have a beautiful voice? To show how fascinating and at the same time illusory fantasies of personal stardom were, 15,000 people completed the survey - but only 300 were deemed to have 'passed.' ${ }^{21}$

Nine months later, Esther Williams ('Star of the Day') was 'quoted' as summarising the ten 'rules' of stardom. While some of these were obvious, even jejune, they also help underline the ways in which American stardom was constructed in order to fit prevailing Turkish ideas on beauty and desirability. A star, according to Williams, ought: 1. to be metropolitan; 2 . to be the best; 3 . to speak many languages; 4 . to dance well; 5 . to have a trained voice; 6 . to have a distinguished look; 7 . to have taste; 8 . to be taller than $175 \mathrm{~cm}$; 9. to be chic; and 10. to have luck. ${ }^{22}$

Two years earlier, Hikmet Feridun Es had profiled six Hollywood stars. The qualities he discerned amongst them also shed light on what personal qualities Turkish writers perceived as essential for stars to have:

Joan Crawford: luck, talent, persistence

Deanna Durbin: photogenic-ness, luck, charm

Jean Blondell: agility, dance, good body

Bette Grable: agility, dance, good body

Clark Gable: sincerity, culture, labour

Spencer Tracy: unlimited love, unlimited knowledge. ${ }^{23}$

All these suggestions for appearance, habits, attractions, skills, knowledge and physical accomplishments not only indicate how Hollywood stars were represented, but also give evidence of the emergence of a new discursive re-configuration of the Turkish body and social behaviour. This re-configuration provided a new set of values and standards (for example, to be sophisticatedly metropolitan) and, by drawing attention to the qualities of individual stars, also pointed to new possibilities for Turkish bodies which had never danced, spoken, acted or looked this 'American' way before. 
The relationship of film and star is a problematic one. John Ellis suggests that the star image is paradoxically incomplete, relying for its completion on the filmic performance. ${ }^{24}$ This raises the question of how the star-oriented discourse - for instance, interviews, backstage stories, gossip - should be weighed against the film performance. Of course, the star persona is not constructed on the basis of the performances of the star and the film alone; the extra-filmic discourse that is produced by the cinematic institution is additionally fed into the persona, always making it something more than the film itself. Therefore, a film performance must be perceived as containing extrafilmic elements as well. The star serves as an intermediary between the audience and the world that the extra-filmic elements construct. The presence of the star on the one hand helps give that world a unity and on the other hand regulates the desire of the audience. So far as Turkish audiences were concerned, the American dream to which Dyer refers would always be read specifically in terms of nationality. For American audiences, Lana Turner was a star, but for Turkish audiences she was an American star, an image which was not only articulated in the diegesis of whatever film she was making but also coalesced with the wider American dream Hollywood presented to all its spectators. As the surveys discussed above revealed, however, the 'America' that Turkish audiences saw and constructed was very much a product of their own imagination and desire. Rather than being a remote, abstract conception, it reflected Turkish values, in the sense that all this was aimed at an identity seeking to re-build itself in what it is not. To Turks, indeed, it was in the most literal sense 'our America'.

Wherever national culture has to articulate a difference and fantasy has to play on this difference, the distance between the object of desire and the subject must be continuously and carefully maintained and disavowed at the same time. America must neither be too close nor too remote. Hollywood presents a fantasy screen to Turkish audiences but it is important that the screen is kept at the right distance. In this case, the correct distance between the screen and the audience is maintained by the mental machinery of the cinematic institution. This becomes clear from the analysis of letters sent to the editors of Turkish movie magazines and the published responses. Generally, the letters themselves fall into two categories: requests (for a missing issue of the magazine or an autographed picture) and enquiries (for the birth date or the correspondence address of a star). One frequently asked question in the second category was 'How can I go to the States?' The magazines' responses were invariably discouraging:

It is impossible to go to America right now. And even if it was possible I wouldn't advise you to do so. It would oblige you to speak a language and complete at least [an] intermediate education ... Do not let yourself be deceived by dreams. The country needs young people ... In previous issues, I dwelled on this frequently and some of my readers got mad at me for not having encouraged them ...

Even if you can go to the States, success is a matter of luck. And to say 'let me give it a try' equals saying 'let me throw myself to the abyss in the dark, maybe I will be saved'.

You cannot go to Hollywood now ... The present circumstances are not convenient for your ambitions. ${ }^{25}$ 
Almost everything else these magazines did negated this practical advice. Outside the correspondence columns, they continued to construct their highly appealing images of America. ${ }^{26}$ Having first acknowledged an impossibility, they then posed it as an object of desire. The ambivalence is made even more evident in announcements of this type:

We are looking for a Betty! A Betty, but a Betty of beautiful Istanbul.

'A Hedy or a Clark - what is it that they've got and you do not?' Instead of dreaming of going to Hollywood to become a star and wasting time with this dull dream, shake up and show yourself! We are giving you the golden key to the doors of our studios. ${ }^{27}$

At the same time as these magazines denied the practicability of any Turk being able to go to America, they encouraged the democratic myth that anyone (even from Turkey) could succeed in becoming a Hollywood star.

Sanitised to some degree by distance, the magazines also dealt with issues such as the immorality of some stars' lifestyles. Such immorality would normally be condemned by Turkish social codes, but escaped such condemnation by being presented essentially as fantasy. According to one magazine in 1946:

If Hollywood were left free, it could have been a city where all moral values were abandoned and it might even have surpassed Sodom ... An enormous income and a life exempt from authority were beginning to seduce the young beautiful girls, handsome young men and the clever businessmen of the land. Crazy meetings, which Americans call 'wild parties', were once very popular. These parties were so crazy that everyone felt free to do whatever he/she wished. ${ }^{28}$

'Enormous income', 'beautiful girls', 'young men', 'a life exempt from authority' and 'wild parties' created a series of fantasy images where everything was allowed.

Many of the male writers on the magazines were plainly fascinated by the issues of how important women were to American cinema and how they were presented in Hollywood films. As one noted, in the first issue of a new magazine:

Aren't vogue and luxury, that the woman loves most, already the two basic elements of the cinema? We see the cinema from her perspective, we see the vogue and luxury in the best possible way. And from the perspective of the film-maker, the woman is an important thing. Otherwise, the most beautiful women of the world would not have gathered in the well-known studios of the world. Is it possible not to envy our colleague Hikmet Feridun Es who is in Hollywood now? To live in the land of beauties, to be in such an atmosphere - even as a viewer; this is what everyone longs for. The woman and the cinema are one inseparable issue. No one can omit the woman from the cinema. If you do not put the woman into the cinema, neither the woman nor the cinema will have a meaning any more ... In short, it is a must to believe in the force that attracts the woman to the cinema and to believe in the woman that attracts us to the cinema. ${ }^{29}$

Ironically, Hikmet Feridun Es, whom the writer envied for being a Turkish correspondent in Hollywood, later recalled a story that underlines the difference between the 
image and the reality of Hollywood. Invited to the wedding party of Bette Grable and Jackie Coogan, he was informed that many stars were going to be present. At the reception in a well-known hotel, he vainly looked for the famous people he expected to see. Finally, he spoke to the head waiter, who suggested that he had not recognised the stars themselves because, in person, they were 'less beautiful than their images in your mind' ${ }^{30}$

Es's story does not undercut the spell of Hollywood. Instead, it stresses what may be seen as the cinema's capacity for producing glamour, transcending the difference between, for instance, Dorothy Lamour the person and the 'Dorothy Lamour' of the movies. What did such glamour itself mean to Turkish audiences? The magazine Prenses (Princess) published a letter from a youthful admirer to Ingrid Bergman. He had already asked his mother to get an autographed picture of Bergman in case she met her in America. When his mother returned with the picture (probably given by the studio?), he wrote a letter to Bergman not only to express his appreciation but also to disclose his love:

I know you receive many letters every day. And I know that this letter will be opened by your secretary. But I also know that you are going to read this letter ... I feel that with an intuition coming from the depths of my soul.

Listen to me Ingrid . . . listen to me, I LOVE YOU MADLY.

Do not let your wonderful lips allow a scorning smile ... Ingrid, I have been loving you for years like crazy ... Any reasonable person can argue that one cannot live with a dream in his mind. But . . . indeed . . . do you think I am an exception? . . I have not ceased dreaming of you for a single moment, Ingrid! ${ }^{31}$

By printing the letter, with its odd mixture of realism and unrequited passion, the magazine presented such behaviour as normal, perhaps even praiseworthy in terms of its emotional commitment to Bergman as a star.

Turkish male journalists who actually visited Hollywood frequently promoted the idea of 'Turkey' as a matter of curiosity and interest to Hollywood stars themselves. Necded F. Uran wrote for the long-established film magazine Yildiz (Star). Uran was shown around the Warner Bros. studio by a Miss Sanchez, secretary to the head of Warners' International Department. During the course of this visit, they met Bette Davis, who was filming The Corn is Green. 'When Bette Davis learned that I was a Turkish journalist', Uran recalled, 'she smiled and motioned me to a seat. "Please, [I'll answer] anything you would like to ask ... But let me add, I would like to know a few things about your country in return." 32 Another writer, Ridvan Mentes, told how he danced with Maria Montez (though, this time, not in Hollywood but in the Hotel George V in Paris). As Mentes recalled:

I was paralysed the moment I saw her. My mind was struck with amazement, only my heart began to pound violently. This mature and worldly wise lady, who understood the state I was in, kindly began to speak to me and ask questions. I was gradually feeling more relaxed. At one moment, she asked about my nationality. When I said that I was a Turk, there was an immediate sincerity in her looks and in the way she spoke... I shyly asked her to dance with me. She didn't refuse. When my arms got around her waist and 
gently held her close to me, I realised that my legs were trembling. I was trying not to make the smallest mistake and the effort made me perspire. Today, when I remember this I cannot help laughing at my situation and smell the scent of that sweet memory. ${ }^{33}$

Although the first story lacks the erotic overtones of the second, both articulate nationality in terms of sexuality: the female star is interested in the male character when she learns that he is a Turk.

\section{Constructing Hollywood's 'Turkish' Star: The Case of Turhan Bey}

The ways in which Turhan Bey, a 'Turkish' star in the Hollywood of the 1940s, was represented to Turkish audiences, shed considerable light on the manner in which film writers constructed a Turkish national identity in relation to Hollywood films. Turhan Gilbert Selahattin Sahultavy, son of a consultant to the Turkish ambassador and Czechoslovakian mother, was born in Vienna in 1920. The family moved to Istanbul when he was a small child. When his parents split up in the 1930s, Turhan moved to the US with his mother and, after studying acting at Ben Bard's School of Dramatic Art and at the Pasadena Playhouse, he began a Hollywood career. Soon he became a popular leading man with his 'exotically handsome looks and well modulated voice. ${ }^{34}$ He starred in some exotic films, such as Mummy's Tomb (1942), Arabian Nights (1942), Sudan (1945), A Night in Paradise (1946), Out of the Blue (1947), The Amazing Mr X (1948), Song of India (1949) and Prisoners of Casbah (1953). When his popularity diminished, perhaps due to the decline of the genre, he left Hollywood for Vienna to start a career in photography. ${ }^{35}$

After his films began to be distributed in Turkey in the mid-1940s, film magazines introduced Turhan Bey as the first and only Turkish star of Hollywood. He became a focus of attention. Readers demanded more information and the magazines were eager to print anything about him. American film companies apparently missed no opportunity to feed the Turkish press publicity. A letter sent by David Blum, the director of the News Service Department of M-G-M, to a popular Turkish film magazine reveals that the studio scanned the media carefully and compiled reviews and news about stars and then mailed them to magazines. ${ }^{36} \mathrm{M}-\mathrm{G}-\mathrm{M}$ had recently signed a contract with Turhan Bey and apparently launched a campaign to promote him. In the same issue of this magazine, there is another section devoted to Turhan Bey's life story, along with two photographs showing him with his mother in one, and with Maria Montez and two Turkish celebrities in the other. ${ }^{37}$

Turhan Bey was constructed in Turkish film periodicals as 'our man in Hollywood'. The magazines were careful to stress his origins and relate him to a national identity:

Particularly, Dragon Seed [M-G-M, 1944] [which] he created together with the great American drama actress Katharine Hepburn suffices to prove that he is going to be a most powerful and brilliant actor in the future. He has spent the first six months of his stay in America learning English. But he has remained faithful to his home country and told us that he would return to Turkey to establish the film industry after the war. Can there be any better news to delight us? Indeed, Turhan Bey has picked a very important issue for our country ... It is impossible for us not to await his return to his homeland soon ... It is the right of every Turk to be proud of Turhan Bey. ${ }^{38}$ 
Turkish journalist Falih Rifki met Turhan Bey in Hollywood. He had the impression that Bey did not look particularly Turkish, describing him as having a face which would best suit 'Chinese stories or 1001 Knights' tales, and also observed that he could not speak Turkish ('But I feel I live within it', Bey ingeniously asserted, and 'two months there would enable me to have good command of the language'). ${ }^{39}$ The crucial issue here is not whether or not Turhan Bey was Turkish, but the degree to which he was constructed as a Turk. The signifier 'Turk' had been attached to him to make him serve as an agent of fantasy as far as Hollywood and its independent-minded women were concerned. Turhan Bey himself played an active role in helping that construction. When asked by Falih Rifki what he thought about 'these Los Angeles marriages', he responded:

Marrying in Los Angeles? But whose woman will your wife be in the morning and in the evening? If you want to get married, you bring your wife from Turkey and keep her in your home. A woman that you can possess. ${ }^{40}$

Turhan Bey's own affair with Lana Turner was widely known when this interview was conducted - he was referred to in gossip columns as 'Lana Turner's Shadow' and she was described (this time offering US readers their own quasi-orientalist fantasy) as the 'American harem girl'. When Turhan Bey was criticised by one reviewer, Turner herself sprang to his defence, calling the journalist and reproaching him for being unfair. 'I have not met anyone as gentle as Turhan Bey in Hollywood,' she claimed. 'I do not understand why you hate this young Turkish actor who comes from an untainted and noble family.' ${ }^{41}$ Fantasy clearly allowed ambivalent situations. Turhan Bey was the fiancé of Lana Turner. He made friends with Maria Montez and other actresses. In other words, he had access to female Hollywood stars. Yet, some Turkish film writers observed, emphasising the gap between fantasy and 'reality', in the end he would probably not marry any of them, preferring a Turkish girl for that purpose. In his interviews, Turhan Bey played on the Turkish moral code when marriage was on the agenda. This made him a perfect object of identification for Turks themselves. A Turkish news report about the possibility of Turhan Bey coming to Turkey noted that:

According to the recent American magazines Turhan Bey will be coming to Turkey to do his military service. Turhan Bey told the journalists that 'I cannot serve in the US Army, otherwise I will lose my Turkish nationality. And I cannot go to Turkey due to the difficulties of travelling. I am awaiting a permit for my departure.' The journalist continues: 'Everyone was expecting that Turhan Bey would be marrying Lana Turner next August. So what is going to become of them if he goes to Turkey?' Let us add something to this: 'So, what? She will pack and follow Turhan Bey to Turkey. And they marry here. ${ }^{42}$

Clearly, as far as Turkish movie writers were concerned, his affair with Lana Turner could only be socially affirmed and legitimated when she was not in Hollywood, but in Turkey. Fantasies were associated with Hollywood; the real was for Turkey and marriage, according to these writers, was no issue of fantasy. Although the magazines repeatedly announced that Turhan Bey would arrive at any moment in his 'homeland', by his own admission Hollywood's archetypal 'Turkish' actor never 'returned' to 
Turkey ${ }^{43}$ His story, however, illustrates the ways in which Hollywood was made more 'accessible' by subjecting it to a degree of fictional 'Turkification': Turhan Bey himself helped to promote identification, while his (Turhan Bey, the Turk's) woman (in this case Lana Turner) served to encourage desire. Turhan Bey's absence from Turkey and presence in America created just the right geographical and psychological distance for Turkish viewers of Hollywood to both identify with and fantasise about him. It was this alternation between identification and fantasy on the part of such Turkish spectators generally, indeed, that allowed them to construct the idea of 'our' (Turkish) America.

\section{Notes}

I wish to thank Peter Kramer and Lewis Johnson for their help.

1 Murat Belge, 'Turkiye'de Gunluk Hayat', Cumhuriyet Donemi Turk Ansiklopedisi (Istanbul: Iletisim, 1995), p. 863.

2 Gezerek Gorduklerim (Istanbul: Devlet Kitaplari, 1970), p. 251.

3 Kim Philby, My Silent War (London: Grafton, 1989), p. 198.

4 Ibid., p. 197.

5 David J. Alvarez, Bureaucracy and Cold War Diplomacy: The United States and Turkey 1943-1946 (Thessaloniki: Institute for Balkan Research, 1980), p. 107.

6 Ibid., p. 110. Ertegun was the father of Ahmet Ertegun, the current head of Atlantic Records.

7 Nezih Erdogan and Dilek Kaya, 'Institutional Intervention in the Distribution and Exhibition of Hollywood Films in Turkey', Historical Journal of Film, Radio and Television, vol. 22, no. 1 (2002), p. 47.

8 Burcak Evren corrects a common mistake that it was a 'D. Hanri' (as indicated in an advertisement), who organised the first public screening in Sponeck, and not Sigmund Weinberg, but Weinberg contributed effectively to the promotion of cinema in Turkey by opening a Pathé office. Evren, Sigmund Weinberg: Turkiye'ye Sinemayi Getiren Adam (Istanbul: Milliyet, 1995), p. 74.

9 Ibid.

10 Giovanni Scognamillo, Cadde-i Kebir'de Sinema (Istanbul: Metis, 1991), p. 98.

11 Ahmet Gurata, 'Imitation of Life: Cross-cultural Reception and Remakes in Turkish Cinema', unpublished doctoral thesis, London Consortium/University of London, 2002.

12 Scognamillo, Cadde-i Kebir'de Sinema, pp. 67-77.

13 Yesilcam'dan Once Yesilcam'dan Sonra (Istanbul: Antrakt, 1996), p. 27.

14 Scognamillo, Cadde-i Kebir'de Sinema, p. 54.

15 Andrew Higson, 'The concept of national cinema', Screen, vol. 30, no. 4 (1989), p. 39.

16 Burcak Evren, Baslangicindan Gunumuze Sinema Dergileri (Istanbul: Korsan, 1993).

17 Sinema Alemi, vol. 1, no. 1 (1944), p. 3.

18 Apparently, some of them were university students who posed as professional journalists.

19 Scognamillo, Cadde-i Kebir'de Sinema, pp. 68-77.

20 Richard Dyer, Stars (London: BFI, 1986), p. 39.

21 'Acaba yildiz olabilir misiniz?', Holivut Dunyasi, no. 66 (February 1945), pp. 13-14.

22 Holivut Dunyasi, no. 94 (November 1945), p. 10. 
23 Hikmet Feridun Es, Hollywood'da 300 Gun (Istanbul: publisher unknown, 1943), pp. 78-9.

24 John Ellis, Visible Fictions (London: Routledge and Kegan Paul, 1982), p. 93.

25 From the Biz Bize column of Hollywood Dunyasi, passim. The editor was anonymous.

26 Nilgun Abisel complains about this attitude in her Turk Sinemasi Uzerine Yazilar (Ankara: Imge, 1994), p. 41 n. 71.

27 Salon-Hollywood Sesi, no. 1 (November 1946), p. 25.

28 Sezai Solelli, Yedigun, no. 673 (27 January 1946), p. 12.

29 Selim Cavit Yazman, 'Kadinin Arkasindan Kostugu Seyler', Yeni Holivut Magazin, no. 1 (March 1948), p. 6.

30 Hollywood'da 300 Gun, p. 34.

31 Translated into Turkish by Prenses Melike Beyza, Prenses, vol. 1, no. 1 (August 1947), p. 7.

32 'Warner Bros.'ta neler gordum?', Yildiz, vol. 14, no. 157 (August 1945), p. 14.

33 'Maria Montez'le bir dans', Prenses, vol. 1, no. 1 (August 1947), p. 2.

34 Bill Tacacs (kinephile@aol.com), http://us.imdb.com/cache/person-all/a14415, accessed 22 December 1997.

35 Forty years later, he returned to America and made guest appearances in a number of television series, also acting in films such as Skateboard Kid II (1995) and Virtual Combat (1996).

36 'Our Weekly News Service has come across an interesting article about Turhan Bey, with whom our company has proudly signed a contract to accompany Katharine Hepburn with an admirable role in Dragon's Seed.

I am enclosing this review with the hope that it will arouse your interest as well as those of your readers. Respectfully yours

David Blum

The Director of News Service, MGM'

Turhan Bey 'in yukselisi', Prenses, vol. 1, no. 1 (August 1947), pp. 18-19. My translation endeavours to preserve the style of the Turkish version.

37 Perin (translating from the late Cevdet Erdem), 'Turhan Bey'i Takdim ederiz', ibid., p. 4.

38 Azmi Turhan, 'Turhan Bey', Holivut Dunyasi, no. 62 (January 1945), pp. 15-16.

39 Gezerek Gorduklerim, p. 236.

40 Ibid., pp. 242-3.

41 'Lana Turner Turhan Bey'in Avukati', Yildiz, vol. 13, no. 150 (May 1945), pp. 15-16.

42 'Turhan Bey Turkiye’ye Geliyor!', Yildiz, vol. 13, no. 155 (July 1945), p. 2.

43 Nezih Erdogan, 'Turhan Bey'i Takdim ederiz', Geceyarisi Sinemasi, no. 4 (spring, 1999), p. 42 . 